\title{
Plant extracts for controlling the post-harvest anthracnose of banana fruit
}

CRUZ, M.E.S. ${ }^{1 *}$; SCHWAN-ESTRADA, K.R.F. ${ }^{1}$; CLEMENTE, E. ${ }^{2}$; ITAKO, A.T.; STANGARLIN, J.R. ${ }^{3}$; CRUZ, M.J.S. ${ }^{1}$

(1) Departamento de Agronomia, (2) Departamento de Química, Universidade Estadual de Maringá, CEP: 87020900, Maringá-PR. Brasil. ${ }^{(3)}$ Universidade Estadual do Oeste do Paraná (UNIOESTE), CEP: 85960-000, Marechal Cândido Rondon-PR. Brasil. "mescruz@wnet.com.br

\begin{abstract}
In banana, fruit rot is incited by Colletotrichum musae which has been the most serious post-harvest disease of immature and mature fruit. The usual control by fungicides prohibited in many countries reduces their commercial value. Therefore, two experiments were conducted to evaluate the antimicrobial activity of alternative products to the synthetic fungicides. First, berries naturally infected by anthracnose were immersed into Azadirachta indica and citric extracts at 2 and $4 \%(\mathrm{v} / \mathrm{v})$ for 3 minutes and stored for 11 days under environmental conditions. Next, other berries were immersed into essential oil emulsions of Allium sativum, Copaifera langsdorfii, Cinnamomum zeylanicum and Eugenia caryophyllata at $5 \%$ for 3 minutes but stored for 11 days. Berries immersed into distilled water were used as control-treatments. The percentage of disease incidence observed in the control-treatment was similar to the ones observed in the extract of $A$. indica at $2 \%$. The control-treatment showed disease severity of $75.13 \%$ and the percentage of disease control was $20.85 \%$. Fruit immersed into distilled water presented less effectiveness than the ones immersed into citric extracts, which promoted the highest effectiveness. Citric extract at $4 \%$ was the most efficient treatment because the disease incidence was $19.44 \%$, the disease severity was $9.34 \%$ and the disease control was $90.16 \%$. Less severity and, consequently, more disease control were achieved by immersing the berries into the emulsion of essential oil of $A$. sativum, followed by treatments with $C$. langsdorfii, $E$. caryophyllata and C. zeylanicum.
\end{abstract}

Keywords: Colletotrichum musae, alternative control, plant extract, essential oil.

RESUMO: Extratos de plantas para controle pos-colheita da antracnose da Banana. Em pós-colheita, a podridão dos frutos causada por Colletotrichum musae é a doença mais importante da banana (Musa spp.), sendo presente em frutos verdes e maduros, tornando o produto pouco apresentável e inadequado à comercialização. Considerando-se os efeitos prejudiciais à saúde do tradicional método químico de controle e a proibição da utilização de fungicidas em muitos países, objetivou-se no presente trabalho avaliar bioprodutos com atividade antimicrobiana, considerados alternativos para o controle de antracnose em banana em póscolheita. Os experimentos foram realizados com frutos de banana naturalmente infectados com Colletotrichum musae, submetidos à imersã, em extratos da planta Azadirachta indica e extratos cítricos (Ecolife), nas concentrações de 2 e $4 \%$ (v/v), permanecendo por 11 dias em condições ambientes. A emulsão composta de óleos essenciais das plantas Allium sativum, Copaifera langsdorfii, Cinnamomum zeylanicum e Eugenia caryophyllata também foi avaliada quanto a sua eficácia no controle do patógeno, permanecendo em condição ambiente por 11 dias. Frutos tratados com água destilada constituíram o tratamento controle. Os resultados obtidos demonstraram que frutos submetidos ao extrato aquoso de $A$. indica na concentração de $2 \%(88,89 \%)$ não diferiu do tratamento controle $(100 \%$ de incidência da doença). O extrato cítrico a $4 \%$ promoveu percentuais de incidência, severidade e controle de 19,44; 9,34 e 90,16\%, respectivamente, sendo o mais eficiente. Menor percentual de severidade e o maior percentual de controle da doença nos frutos foram proporcionados pela emulsão óleos essenciais de $A$. sativum, seguidos pelos tratamentos com $C$. langsdorfii, E. caryophyllata e C. zeylanicum.

Palavras-chave: Colletotrichum musae, controle alternativo, extrato vegetal, óleo essencial.

Recebido para publicação em 30/05/2011

Aceito para publicação em 17/09/2013

Rev. Bras. PI. Med., Campinas, v.15, n.4, supl.I, p.727-733, 2013. 


\section{INTRODUCTION}

In terms of tropical fresh fruit market, banana (Musa paradisiaca L.) has been one of the main world exports because the annual sales have been reaching about US\$ 5 billion. India, Equator, Brazil and Philippines are the greatest producers although most of the national production is sold in the domestic market which made Brazil the first consumer in the world (Cordeiro and Matos, 2000). Modern crop production and efficient fruit distribution, however, are still necessary to increase net profits and stimulate the national capacity of fruit exportation which accounts for no more than $1 \%$ to Argentina and Uruguay, for example. In Brazil, the current production systems need essential improvements because many on-farm constraints have often contributed to reduce the quality of banana fruit. The main constraint in the productive chain has been the large losses in the post-harvest period because the national know how for storing, transporting and handling banana fruit is still incipient. Losses have been estimated between 40 and $50 \%$ of six million of metric tons and most of them are caused by postharvest diseases (Kluge et al., 2007).

Pitting (Pyricularia grisea), fruit rot (Colletotrichum musae), Ceratocystis fruit rot (Ceratocystis paradoxa) and crown rot, which are a complex of diseases incited by Cephalosporium sp., Verticillium theobromae, Fusarium roseum, Fusarium moniliforme, Botryodiplodia theobromae, C. musae, Deighthoniella torulosa and C. paradoxa, are the most common post-harvest diseases (Manica, 1997). The most important is the fruit rot whose control must start early under field conditions through proper harvesting, transporting and handling practices because mechanical injuries incite the development of diseases (Chitarra and Chitarra, 2005; Cordeiro and Matos, 2000). Anthracnose symptoms are characterized by depressed and brown spots from developing acervuli orangesalmon color under conditions of high humidity. They coalesce and dominate all the peel of the mature fruit. The fruit pulp is also affected under high storage temperatures (Cordeiro and Kimati, 2005; Cordeiro and Matos, 2000).

The control of postharvest diseases tends to methods in which commercial products should activate defense mechanisms of plants. The focus is the resistance induction (James et al., 1993) because environmental politics worldwide have been questioning the excessive use of agrochemicals (Stadnik and Talamini, 2004). As researchers are looking for alternatives to these agrochemicals (Mari and Guizzardi, 1998), consistent responses from alternative methods have suggested applying essential oils or crude plant extracts because they have fungitoxic action and induce fruit resistance through proper elicitor compounds (Stangarlin et al., 1999; Schwan-Estrada and Stangarlin, 2005). Garlic extracts, for example, inhibited the development of Pythium ultimum, Colletotrichum lindemuthianum and Rhizoctonia solani; the extracts and oils of Azadirachta indica (neem) had effective control on tomato oidium (Oidium lycopersici); essential oils of Thymus vulgaris, Lavandula sp. and Mentha piperita controlled $C$. lindemuthianum and $P$. ultimum; essential oils extracted from the leaves of Cinnamomum zeylanicum L. and fruit of Syzygium aromaticum L., sin. Eugenia caryophyllata, Thunb controlled the anthracnose (C. musae) of banana fruit (Bianchi et al. 1997; Carneiro, 2003; Zambonelli et al.,1996; Ranasinghe et al., 2002).

Therefore, the objective of the present experiment was to evaluate doses of the essential oils and plant aqueous extracts (from leaves) on the effective control of the post-harvest anthracnose of banana fruit.

\section{MATERIALS AND METHODS}

Two experiments were conducted at the Laboratory of Food Transformation, Preservation and Medicinal Plants, in the Department of Agronomy, in the Universidade Estadual de Maringá. Banana clusters of the cultivar Nanica (Musa, genome group AAA and subgroup Cavendish) were collected in green groceries at the CEASA, the national company that supplies fruit and vegetables for the municipality of Maringá, Northwestern Paraná, Brazil. The fruit clusters were divided into groups of three berries for proper packing into plastic boxes. They were first rinsed into sodium hypochlorite at 5.0\% (v/v) for 3 minutes, washed two times in tap water, and then dried under natural weather conditions.

The extracts and essential oils tested in the experiments were purchased from Herbarium Botanical Laboratory Ltda., Biosapiens, Quinabra, Neal's Yard Remedies in Brazil and Agricultural El Sol / Guatemala. The solutions used in treatments were obtained by dilution of plant products (from leaves) in distilled water, in suitable concentrations ( 2 or $4 \% \mathrm{v} / \mathrm{v}$ ).

Experiment I: Naturally infected berries were immersed into $A$. indica $A$. Juss or citric extracts at 2 or $4 \%(v / v)$ for 3 minutes. These treatments were compared to control-treatments in which the berries were immersed into distilled water for 3 minutes. Thereafter, all berries were packed into plastic boxes protected by polyethylene films and stored at $24 \pm$ $2^{\circ} \mathrm{C}$ in condition of relative humidity of $85 \pm 5 \%$ for 11 days when all berries in the control-treatments developed the anthracnose symptoms.

In both experiments, the designs were

Rev. Bras. PI. Med., Campinas, v.15, n.4, supl.I, p.727-733, 2013. 
completely randomized with 5 treatment and 4 replications where every experimental unit had 3 groups of 3 berries. All the statistical analyses were carried out by using the SAEG 8.0 and the data set were evaluated by analyzes of variance and the means compared by the test of Duncan at $5 \%$ of probability (Ribeiro Jr., 2001).

Experiment II: Naturally infected berries were immersed into solutions of essential oils of A. sativum, C. langsdorfii, C. zeylanicum, and $E$. caryophyllata at $5.0 \%(\mathrm{v} / \mathrm{v})$ for 3 minutes. These treatments were compared to control-treatments in which the berries were also immersed into the distilled water for 3 minutes. Tween 20 was used as emulsifier because it does not affect the antimicrobiological characteristics of essential oils (Carson et al., 1995; Willians, 1990). Next, all berries were also packed into plastic boxes protected by polyethylene film and stored at $24 \pm 2^{\circ} \mathrm{C}$ relative humidity of $85 \pm 5 \%$ for 11 days when all berries in the control-treatments developed the anthracnose symptoms.

The fruit quality was evaluated by the percentage of biomass reduction determined by the difference between the initial and final biomass weighed on semi-analytical scale, the transversal diameter $(\mathrm{mm})$ measured at the median section of every berry by using digital caliper and the fruit length measured at the convex face of the pulp by using a flexible ruler. Changes in the berry peel color were evaluated by numeric scales (Chitarra and Chitarra, 2005; Von Loesecke, 1950) in which the green $=1$, green trace of yellow $=2$, more green than yellow $=3$, more yellow than green $=4$, green tip $=5$, all yellow $=6$, yellow spotted with brown $=7$ and the additional scale brown $=8$.

The percentage of diseased fruit (Amorim, 2005) was calculated by counting the number of berries with anthracnose symptoms. The disease severity was calculated after using a digital caliper for measuring the average diameter of the lesions at both horizontal and vertical perpendicular positions. The results were reported as the percentage of injured area (Mendez and Mondino, 1999). The percentage of disease control was calculated through the average diameter of the lesion.

\section{RESULTS AND DISCUSSION}

\section{Experiment 1}

All treatments had the parameters biomass reduction, transverse diameter and fruit length statistically higher than the control. Fruit immersed into the crude plant extracts presented different estimates for biomass and length reduction and fruit immersed into the citric extract at $4 \%$ presented lower losses. No statistical difference was detected in the fruit diameter when they were immersed into extracts of $A$. indica at $4 \%$ and citric extract at 2 or $4 \%$ (Table 1). The explanation for these findings is that both treatments may have promoted the highest pathogen control. All treatments, however, presented losses in biomass, diameter and fruit length because of the inherent maturation of these climacteric fruit (Table 1). The storage at $24 \pm 2^{\circ} \mathrm{C}$ for 11 days increased the respiratory activity because increases in ethylene production by fruit and pathogens were favored by environmental temperatures. In the present experiment, possibly the origin of the anthracnose may rest on latent infection in the immature peel where the fungus stayed dormant up to the beginning of the maturation or non-latent infection which was incited by mechanical injuries.

Fruit quality based on commercial standards established by international regulatory acts has been considering the fruit biomass, diameter, size and peel color as parameters economically determinant in most fruit markets. The first three parameters are quantitative traits that may be reduced by losses of water, biomass or both (Alves et al., 1999; Brasil, 2000). Moreover, damages during pre-harvesting, harvesting and handling practices increase the quantitative losses and permit the growth and development of pathogens (Chitarra and Chitarra, 2005; Crisosto et al., 1997). Therefore, the presence of anthracnose on the control fruit explains the highest reduction in biomass, diameter and fruit length because this pathogen depletes the fruit reserves and the ethylene accelerates the fruit senescence (Flaishman and Kolattukudy, 1994).

Antifungal activity of citric extracts was reported by Jansen et al. (1995) and Krauss and Johanson (2000) who studied extracts of citric seeds at $250 \mathrm{ppm}$ under the post-harvest period. This biofungicide approved by the organic market has been satisfactory in the control of crown rot and anthracnose of banana fruit. Miranda et al. (2003) immersed fruit clusters into different concentrations of citric extract or Benomyl at $0.25 \%$ under 7 , 20 and $40^{\circ} \mathrm{C}$ to evaluate biomass, hull and pulp, pulp-to-hull ratios, $\mathrm{pH}$ and total acidy. All doses of citric extract presented similar responses for pulp biomass and they were better than the control. The effects of hot water and oil extracts from $A$. indica and Xylopia aethiopica were evaluated by Amadioha and Obi (1998) who reported significant decreases in the spore germination, in vitro growth of $C$. lindemuthianum, and effective reduction in the lesion area by the treatment with oil extracts. $A$. indica and $X$. aethiopica had higher fungitoxic effects than benomyl when the extracts were applied to Vigna unguiculata either before or after infecting the plants. Dhingra (2000) reported the efficacy of $A$.

Rev. Bras. Pl. Med., Campinas, v.15, n.4, supl.I, p.727-733, 2013. 
indica extracts on Rhizoctonia solani and the seed oil for controlling Botrytis cinerea, Penicillium expansum and Glomerella cingulata on stored apple fruit.

All treatments significantly modified the peel color (Table 1). Control fruit were inappropriate to consumption because they reached the scale 8 and showed the symptoms of the anthracnose. Berries immersed into the citric extract at $4 \%$ were classified between green tips (scale 5 ) and completely yellow (scale 6); berries immersed into the citric extract at $2 \%$ had excellent quality (scale 6) which was similar to the quality of those berries immersed into the extract of $A$. indica at 2 and $4 \%$. Peel color is the primary qualitative criterion of consumers in making purchasing decision although the appearance does not make any contribution to the nutritive value despite color changes are caused either by biosynthetic or degenerative processes (Chitarra and Chitarra, 2005).

Upon maturation, the pulp is always softened, the starch is transformed into glucose and the chlorophyll is oxidized. The gradual chlorophyll oxidation stimulates the appearance of carotene and xanthophylls although they also depend on the handling practices and storage conditions (Kluge et al., 2007). The scale 5 denoted the direct effects of the extracts on the pathogen and, consequently, reducing the rate of peel color modification on berries immersed into citric extracts at $4 \%$.

One hundred percent of disease incidence observed in the control-treatment was similar to the effect of the extract obtained from $A$. indica at $2 \%$ unlike at $4 \%$. Citric extracts at 2 and $4 \%$ presented the best estimates (Table 2). The use of disease incidence to quantify the anthracnose was considered adequate because just one spot is capable of eliminating a berry from the produce sections (Amorim, 2005). These responses are also interesting because berries immersed into extracts of $A$. indica and control had more than $66.67 \%$ of disease incidence and detrimental incidence of fruit rot was also detected even in those treatments with citric extracts. Otherwise, the intensity or the area affected by the disease minimized the responses of incidence in which estimates of disease severity indicated more precisely the anthracnose intensity because of the lesion diameter.

When the disease severity was evaluated, the control fruit had estimates significantly higher than other treatments. The immersion into the extracts of $A$. indica at $2 \%$ was higher than $4 \%$ and both were higher than the citric extract at $2 \%$ and $4 \%$ (Table 2). The different levels of severity were evidences of fungicide activities. Just one lesion determines the incidence but not as severe as the presence of numerous lesions capable of incite tissue necroses and, consequently, fruit death. Therefore, the severity was more precise to identify the fruit rot intensity because of the average diameter of lesions.

The percentage of disease control was significantly different when compared $A$. indica and citric extracts. In the control-treatment, the percentage was lower than in the others. The percentage control of extracts of $A$. indica at $2 \%$ was lower than $4 \%$ and both were different from treatments prepared with citric extract at $4 \%$, for example, which had $90.16 \%$ and promoted the most efficient control (Table 2). These results are in agreement with Fortes et al. (2002), who studied the efficiency product based on citric biomass in different concentration on the inhibition of the growth of $C$. lindemuthianum and $R$. solani in comparison with Cerconyl $\left(20 \mathrm{mg} \mathrm{L}^{-1}\right)$. They found that the $C$. lindemuthianum was more sensitive to the doses of citric biomass. The extract of $A$. indica, in the present

TABLE 1. Percentage of biomass reduction, transversal diameters, fruit length and peel color scales of banana fruit infected by Colletotrichum musae and immersed into different concentration of plant and citric extracts.

\begin{tabular}{lcccc}
\hline \multirow{2}{*}{ Plant extracts } & \multicolumn{2}{c}{ Reduction (\%) } & \multicolumn{2}{c}{ Peel color } \\
\cline { 2 - 5 } & \multicolumn{1}{c}{ Biomass } & Diameter & Length & Scales \\
\cline { 2 - 5 } & $7.05 \mathrm{a}$ & $7.50 \mathrm{a}$ & $7.71 \mathrm{a}$ & $8.00 \mathrm{a}$ \\
\hline Control & $5.02 \mathrm{~b}$ & $5.09 \mathrm{~b}$ & $4.80 \mathrm{~b}$ & $7.00 \mathrm{~b}$ \\
A.indica (2\%) & $3.92 \mathrm{c}$ & $3.16 \mathrm{c}$ & $3.97 \mathrm{c}$ & $6.50 \mathrm{bc}$ \\
A.indica (4\%) & $2.90 \mathrm{~d}$ & $1.86 \mathrm{~cd}$ & $2.95 \mathrm{~d}$ & $6.00 \mathrm{c}$ \\
Citric extract (2\%) & $1.52 \mathrm{e}$ & $1.34 \mathrm{~d}$ & $0.54 \mathrm{e}$ & $5.25 \mathrm{~d}$ \\
Citric extract (4\%) & 3.44 & 20.36 & 2.60 & 5.22 \\
\hline CV (\%) & & &
\end{tabular}

In the columns, means followed by the same small letter are not statistically different by the Duncan test at $5 \%$ of probability. ${ }^{* *}$ Peel color green $=1$; green trace of yellow $=2$; more green than yellow $=3$; more yellow than green $=4$; green tip $=5$; all yellow $=6$; yellow spotted with brown $=7$; brown $=8$.

Rev. Bras. PI. Med., Campinas, v.15, n.4, supl.I, p.727-733, 2013. 
experiment, was not so effective although it permitted a significant control because the $A$. indica has a chemical characteristic common to Meliaceae, i.e. the presence of meliacine and limonoids in leaves, fruit and seeds (Neves et al., 2003). Compounds like nimbidin, nimbin and quercetine present in the A. indica have been causing the fungicide activities (Phytochemical and Ethnobotanical DatabasesUSDA, 2003).

\section{Experiment 2}

Lower biomass reduction was obtained when berries were immersed into the essential oil of A. sativum, but followed by higher losses in biomass and diameter when they were immersed into the essential oil of C. langsdorfii, E. caryophyllata and C. zeylanicum. These treatments, however, were significantly different from the control in which the berries had the worst quality. The length of control fruit was similar to the essential oil of $C$. zeylanicum but different from other treatments where the essential oil of $A$. sativum caused lower reduction (Table 3).
The peel color from the control fruit was similar to the responses from the $C$. zeylanicum. In both treatments, all berries were unsuitable for in natura consumption because the peel color reached the scale 8 (Table 3). Brown spots similar to the description of Kanerva et al. (1996) indicate metabolic substances in the oil composition capable of inciting toxicity symptoms as peel scars and burning. Therefore, the dose of essential oils to evaluate biological activities must be the minimum capable of causing fungistatic or fungicide effects. Berries immersed into solutions of $C$. langsdorfii and E. Caryophyllata presented similar results but they were different from the previous treatments and the immersion into the $A$. sativum in which the peel color was the yellow (scale 6). This scale is an excellent stage for consumption. Technical procedures cause modification in the maturation rate because of enzymatic activities, biotic or non-biotic factors which may affect the balance of pigments in the peel (Manica, 1997; Chitarra and Chitarra, 1984).

Disease incidence was lower $(22.22 \%)$ in berries immersed into the essential oil of $A$. sativum

TABLE 2. Mean values of disease incidence, lesion diameter, severity and anthracnose control of banana fruit infected by Colletotrichum musae and immersed into different concentration of plant extracts.

\begin{tabular}{lcccc}
\hline \multirow{2}{*}{ Plant extracts } & \multicolumn{4}{c}{ Disease } \\
\cline { 2 - 5 } & Incidence & Lesion & Severity & Control \\
\hline & $\%$ & $\mathrm{~cm}$ & $\%$ & $\%$ \\
Control & $100.00 \mathrm{a}$ & 4.13 & $75.13 \mathrm{a}$ & $20.85 \mathrm{~d}$ \\
A.indica (2\%) & $88.89 \mathrm{a}$ & 3.04 & $55.30 \mathrm{~b}$ & $41.73 \mathrm{c}$ \\
A.indica (4\%) & $66.67 \mathrm{~b}$ & 1.57 & $40.03 \mathrm{c}$ & $57.83 \mathrm{~b}$ \\
Citric extract (2\%) & $33.33 \mathrm{c}$ & 1.10 & $20.08 \mathrm{~d}$ & $78.85 \mathrm{a}$ \\
Citric extract (4\%) & $19.44 \mathrm{c}$ & 0.51 & $9.34 \mathrm{~d}$ & $90.16 \mathrm{a}$ \\
\hline CV (\%) & 17.86 & & 18.94 & 13.78 \\
\hline
\end{tabular}

In the columns, means followed by the same small letter are not statistically different by the Duncan test at $5 \%$ of probability.

TABLE 3. Mean values of biomass reduction, transversal diameter, fruit length and peel color of banana fruit infected by Colletotrichum musae and immersed into essential oils

\begin{tabular}{lcccc}
\hline \multirow{2}{*}{ Essential oils } & \multicolumn{3}{c}{ Reduction (\%) } & Peel color \\
\cline { 2 - 5 } & Biomass & Diameter & Length & Scales \\
\hline & $\mathrm{g}$ & $\mathrm{cm}$ & $\mathrm{cm}$ & $* *$ \\
Control & $15.44 \mathrm{a}$ & $12.33 \mathrm{a}$ & $8.03 \mathrm{a}$ & $8.00 \mathrm{a}$ \\
C. zeylanicum (5\%) & $12.89 \mathrm{~b}$ & $8.79 \mathrm{~b}$ & $7.53 \mathrm{a}$ & $8.00 \mathrm{a}$ \\
E. caryophyllata (5\%) & $10.74 \mathrm{c}$ & $6.07 \mathrm{c}$ & $5.88 \mathrm{~b}$ & $7.00 \mathrm{~b}$ \\
C. langsdorfii (5\%) & $6.76 \mathrm{~d}$ & $4.45 \mathrm{~d}$ & $2.98 \mathrm{c}$ & $6.75 \mathrm{~b}$ \\
A. sativum (5\%) & $3.79 \mathrm{c}$ & $2.93 \mathrm{e}$ & $0.65 \mathrm{~d}$ & $6.25 \mathrm{c}$ \\
\hline CV (\%) & 8.47 & 4.89 & 1.79 & 4.39
\end{tabular}

In the columns, means followed by the same small letter are not statistically different by the Duncan test at $5 \%$ of probability.

${ }^{* *}$ Peel color green $=1$; green trace of yellow $=2$; more green than yellow $=3$; more yellow than green $=4$; green tip = 5; all yellow $=6$; yellow spotted with brown $=7$; brown $=8$. 
which were also different from the other results. Berries immersed into the solutions of $C$. zeylanicum and control had $100 \%$ of symptoms unlike the berries immersed into the essential oil of E. caryophyllata (72.22\%) followed by C. Langsdorfii (58.33\%) which were also different (Table 4). Severity and disease control were also different in all treatments (Table 4). The lowest disease severity and the highest percentage of disease control were detected by fruit immersion into essential oils of $A$. sativum. These means were followed by those estimates from treatments with C. langsdorfii, E. caryophyllata and C. Zeylanicum. In the control treatment, otherwise, where the percentage of disease control was just $5.19 \%$, the severity was $92.39 \%$.

Antimicrobial activities of plant extracts have been confirmed by several researches in which the fungi development in vitro and in vivo was affected. Spore formation and germination, the mycelia growth and the infection may be stimulated or inhibited by the plant extracts. In some post-harvest experiment, plant extracts have inhibited the fruit rot development while, in other, the effects have been fungistactic because of selective activities. In this study were observed that the plants had both activities.
Furthermore, differences in fungicide activity have been associated to solvents, plant components under study, harvesting time and weather conditions (Bautista-Baños et al., 2003). The anthracnose control by $A$. sativum is caused by the presence of various plant compounds as acetaldehyde, ajoene, allicin, alpha-phellandrene, beta-phellandrene, caffeic acid, chlorogenic acid, citral, diallyl-disulfide, eruboside-b, feluric-acid, geraniol, iodine, linalol, p-coumaric acid, pectin, phloroglucinol, selenium and sinapinic acid (USDA, 2003). Finally, different doses, methods of application, pathogens, host plants and weather conditions are compelling arguments for further investigation.

\section{CONCLUSION}

The plant extracts and the essential oils had effective action on the conservation and disease control of post-harvest banana fruit. First, losses in biomass, diameter and fruit length were lower in the citric extract and $A$. sativum and both treatments preserved the best peel color. Second, lower incidence, disease severity and the highest percentage of anthracnose control were also observed after using these natural products

TABLE 4. Mean values of disease incidence, lesion, severity and anthracnose control of banana fruit infected by Colletotrichum musae, immersed into medicinal solution, and evaluated after storage for 13 days under environmental conditions $\left(26 \pm 2^{\circ} \mathrm{C}\right.$ and $90 \pm 5 \%$ U.R.)

\begin{tabular}{lcccc}
\hline \multirow{2}{*}{ Essential oils } & \multicolumn{4}{c}{ Disease evaluation } \\
\cline { 2 - 5 } & Incidence & Lesion & Severity & Control \\
\hline Control & $(\%)$ & $(\mathrm{cm})$ & $(\%)$ & $(\%)$ \\
\hline C. zeylanicum (5\%) & $100.00 \mathrm{a}$ & 5.08 & $92.39 \mathrm{a}$ & $5.19 \mathrm{e}$ \\
\hline E. caryophyllata (5\%) & $100.00 \mathrm{a}$ & 3.55 & $64.57 \mathrm{~b}$ & $33.75 \mathrm{~d}$ \\
\hline C. langsdorfii (5\%) & $72.22 \mathrm{~b}$ & 1.30 & $23.55 \mathrm{c}$ & $75.83 \mathrm{c}$ \\
\hline A. sativum (5\%) & $58.33 \mathrm{c}$ & 0.90 & $16.31 \mathrm{~d}$ & $83.26 \mathrm{~b}$ \\
\hline CV $(\%)$ & $22.22 \mathrm{~d}$ & 0.74 & $11.81 \mathrm{e}$ & $86.27 \mathrm{a}$ \\
\hline
\end{tabular}

In the columns, means followed by the same small letter are not statistically different by the Duncan test at $5 \%$ of probability.

\section{REFERENCE}

ALVES, E.J.; MEDINA, W.M.; OLIVEIRA, M.A. Colheita e manejo pós-colheita. In. Alves, E. J. (Ed.). A cultura da banana: aspectos técnicos, socioeconômicos e agroindustriais. 2. ed. Brasília: EMBRAPA, 1999, p. 453-486.

AMADIOHA, A.C.; OBI, V.I. Fungitoxic Activity of Extracts from Azadirachta indica and Xylopia aethiopica on Colletotrichum lindemuthianum in Cowpea. Journal of Herbs, Spices \& Medicinal Plants. University of Massachusetts, Amherst. Ed: Lyle E. Craker. The HAWORTH Press. Inc. v. 6, nº 2. Resumo 33, 1998.
AMORIM, L. Avaliação de doenças. In: BERGAMIN FILHO, A.; KIMATI, H.; AMORIM, L. Manual de Fitopatologia. São Paulo: Agronômica Ceres, Cap. 32, 2005, p.647-671.

BAUTISTA-BAÑOS, S.; HERNÁNDEZ-LÓPEZ, M.; BOSQUEZ-MOLINA, E.; WILSON, C. L. Effects of chitosan and plant extracts on growth of Colletotrichum gloeosporioides, anthracnose levels and quality of papaya fruit. Crop Protection, v.22, p. 1087-1092, 2003.

BIANCHI, A.; ZAMBONELLI, A.; D'AURELIO, A.Z.; BALLESIA, F. Ultrastructural studies of the effects of Allium sativum on phytopathogenic fungi in vitro. Plant

Rev. Bras. PI. Med., Campinas, v.15, n.4, supl.I, p.727-733, 2013. 
Disease, v.81, p.1241-1246, 1997.

BRASIL., 2000. Ministério da Integração Social. Banana. Brasília. 8 p. (Frutiséries, 6).

CARNEIRO, S.M.T.P.G. Efeito de extratos de folhas de nim sobre o oídio do tomateiro. Summa Phytopathologica, v.29 n.3, p.262-265, 2003.

CARSON, C.F.; HAMMER, K.A.; RILEY, T.V. Broth micro-dilution method for determining the susceptibility of Escherichia coli and Staphylococcus aureus to the essential oil Melaleuca alternifolia (tea tree oil). Microbios, Cambridge, v.82 n.332, p.181-5, 1995.

CHITARRA, M.I.F.; CHITARRA, A.B. Pós-colheita de frutos e hortaliças: fisiologia e manuseio. Lavras: ESAL/FAEPE, 2005, 785p.

CHITARRA. A.B.; CHITARRA, M.I.F. Manejo pós- colheita e amadurecimento comercial de banana. Pesquisa Agropecuária Brasileira, Brasília, v.19. n. 6, p. 761771, 1984.

CORDEIRO, Z.J.M.; KIMATI, H. Doenças da bananeira (Musa spp.). In: KIMATI, H.; AMORIM, L.; BERGAMIN FILHO, A.; CAMARGO, L. E. A.; REZENDE, J. A. M. Manual de Fitopatologia. Vol. 2. São Paulo: Agronômica Ceres. Cap. 13, 2005, p.112-136.

CORDEIRO, Z.J.M.; MATOS, A.P. Doenças fúngicas e bacterianas. In: CORDEIRO, Z. J. M. Banana: Fitossanidade. Brasília: EMBRAPA, 2000, 121p.

CRISOSTO, C.H.; JOHNSON, R.S.; DEJONG, T. Orchard factors affecting post harvest stone fruit quality. HortScience, v. 32 n. 5, p. 820-823, 1997.

DHINGRA,J. Neem. Panacea for all maladies. Agriculture Tribune. November, 1999. Disponível em <http://www.tribuneindia.com/1999/99nov29/agro.htm>. Acesso em: 09 de jul de 2000.

FLAISHMAN, M.A.; KOLATTUKUDY, P.E. Timing of fungal invasion by using host's ripening hormone as a signal. Proceedings of the National Academy of Sciences of the USA, v. 91 n. 14, p. 6579-6583, 1994.

FORTES, N.L.P.; DIB, A.P.; YAN, A.W.T.; SOUZA, A.D. Avaliação da aplicação de biomassa cítrica (Lonlife) e cerconil no crescimento micelial de C. lindemuthianum e Rhizoctonia solani. Anais II Encontro de Iniciação Científica da Universidade de Taubaté, 1997. Departamento de Ciências Agrárias da Universidade de Taubaté - Taubaté - SP. Disponível em <http://www.unitau.br/prppg/inicient/iieic/anais4bi.htm> Acesso em: 09 de julho de 2002.

JAMES, J.R., TWEEDY, B.G. Y NEWBY, L.C. Efforts by industry to improve the environment safety of pesticides. Annual Review of Phytopathology. v. 31, p. 423-439, 1993.

KANERVA, L.; ESTLANDER, T.; JOLANKI, R. Occupational allergic contact dermatitis from spices. Contact Dermatitis, v. 35 n. 3, p. 157-62, 1996.

KLUGE, R.A.; AGUILA, J.S.D.; JACOMINO, A.P.; SCARPARE FILHO, J.A. Colheita e Climatização de Banana. Piracicaba: ESALQ, Divisão de Biblioteca e Documentação, Boletim Série Produtor Rural, n. 35,
2007.

KRAUSS, U.; JOHANSON, A. Recent advances in the control of crown rot of banana in the Windward Islands. Crop Protection, v. 19, p. 151-160, 2000.

MANICA, I. Fruticultura tropical 4: banana. Porto Alegre: Cinco Continentes, 1997, 485p.

MARI, M.; GUIZZARDI, M. The postharvest phase: emerging technologies for the control of fungal diseases. Phytoparasitica, v. 26 n. 1, p. 59-66, 1998.

MENDEZ, S.V.; MONDINO, P. Control biológico postcosecha en Uruguay. Horticultura Internacional, v. 7, p. 29-36, 1999.

MIRANDA, I.A.; GIRARDI, V.T.; SILVA, A.A.; SILVA, A.L.B., 2003. Avaliação de doses de lonlife na póscolheita da banana (Musa sp. cv. "nanicão"). Unitau. Disponível em: <http://www.unitau.br/prppg/inicient/iieic/ anais5bi.htm>. Acesso em: 15 de outubro de 2003.

NEVES, B.P.; OLIVEIRA, I.P.; NOGUEIRA, J.C.M. Cultivo e utilização do Nim indiano. Goiânia: EmbrapaCNPAF-APA, 32p. (Circular Técnica, 62). 2003.

RANASINGHE, L.; JAYAWARDENA, B.;ABEYWICKRAMA, K. Fungicidal activity of essential oils of Cinnamomum zeylanicum (L.) and Syzygium aromaticum (L.) Merr et L.M.Perry against crown rot and anthracnose pathogens isolated from banana. Letters in Applied Microbiology, v. 35 n. 3, p. 208-211, 2002.

RIBEIRO JUNIOR, J.I. Análises estatísticas no SAEG. Viçosa: UFV, 2001. 301p

SCHWAN-ESTRADA, K.R.F.; STANGARLIN, J.R. Extratos e óleos essenciais de plantas medicinais na indução de resistência. In: CAVALCANTI, L.S.; DI PIERO, R.M.; CIA, P.; PASCHOATI, S.F.; RESENDE, M.L.V.; ROMEIRO, R.S. Indução de resistência em plantas a patógenos e insetos. Piracicaba: Fealq, p. 125-132. 2005.

STADNIK, M.J.; TALAMINI, V. Manejo ecológico de doenças de plantas. Florianópolis, SC: UFSC, 2004, 293p.

STANGARLIN, J.R.; SCHWAN-ESTRADA; K.R.F.; CRUZ, M.E.S.; NOZAKI, M.H. Plantas Medicinais: plantas medicinais e controle alternativo de fitopatógenos. Biotecnologia Ciência \& Desenvolvimento, v.11, p. 16-21, 1999.

USDA, ARS. National Genetic Resources Program. Phytochemical and Ethnobotanical Databases. [Online Database] National Germplasm Resources Laboratory, Beltsville, Maryland. 2003.

VON LOESECKE, H.W. Banana: Chemistry, Physiology, Technology. $2^{\text {nd }}$ ed. New York: Innterscience Publishers. Pp. 52-66. 1950.

WILLIANS, L.R. Antimicrobial activity of oil of melaleuca (tea tree oil). Its potential use in cosmetics and toiletries. Cosmet Aerosols Toil Aust, v. 4 n. 4, p. 12-22, 1990.

ZAMBONELLI, A.; D'AURELIO, A.Z.; BIANCHI, A.; ALBASIN,A. Effects of essential oils on phytopathogenic fungi in vitro. Journal of Phytopathology, v.144, p.491494, 1996.

Rev. Bras. PI. Med., Campinas, v.15, n.4, supl.I, p.727-733, 2013. 